$\overline{\overline{\text { BRUSSELS }}} \overline{\overline{\text { STUDIES }}}$

\section{Brussels Studies}

La revue scientifique électronique pour les recherches sur Bruxelles / Het elektronisch wetenschappelijk tijdschrift voor onderzoek over Brussel / The e-journal for academic research on Brussels

Notes de synthèse | 2009

\title{
Veiligheid in Brussel
}

Synthesenota, SGB nr. 2

La sécurité à Bruxelles

Security in Brussels

Christophe Mincke, Sybille Smeets et Els Enhus

Traducteur : Daniel Struys

\section{OpenEdition}

\section{Journals}

Édition électronique

URL : http://journals.openedition.org/brussels/886

DOI : 10.4000/brussels.886

ISSN : 2031-0293

Éditeur

Université Saint-Louis Bruxelles

Référence électronique

Christophe Mincke, Sybille Smeets en Els Enhus, « Veiligheid in Brussel », Brussels Studies [Online]

Synthesenota's, Online op 05 janvier 2009, geraadpleegd op 30 avril 2019. URL : http:// journals.openedition.org/brussels/886 ; DOI : 10.4000/brussels.886 
RUXELLES

RUSSEL RUSSELS

www.statengeneraalvanbrussel.be

\title{
Synthesenota nr. 2
}

\section{Veiligheid in Brussel}

\author{
Chr. Mincke, S. Smeets, E. Enhus \\ Vertaling: Daniel Struys
}

- Christophe Mincke is doctor in de rechten en socioloog, gastprofessor aan de Facultés Universitaires Saint-Louis (FUSL) en redactiesecretaris van Brussels Studies. Hij is lid van het "Institut de recherches interdisciplinaires sur Bruxelles" (IRIB FUSL) en van het "Centre d'Etudes Sociologiques" van de FUSL. Hij heeft onderzoek verricht naar de toepassing van de strafrechtbemiddeling in Brussel en de buurproblematiek en houdt zich momenteel bezig met de relaties tussen de mobiliteitslogica en de strafwetgeving. Hij is de auteur van het werk "La proximité dangereuse. Médiation pénale belge et proximité”, Droit et société, 2006, nr. 63-64, p. 459 tot 487.

Contact : mincke@fusl.ac.be - 02/211.78.22

- Sybille Smeets is doctor in de criminologie en politologe. Zij werkt als assistentprofessor aan de "Ecole des sciences criminologiques" van de Université Libre de Bruxelles. Haar voornaamste onderzoeksdomeinen zijn de politie, de politiefunctie en de het beleid van de lokale besturen op veiligheidsgebied. Zij publiceerde onder andere "New uniforms of local governance of security in Belgium: between shift of police function and 'activation of good citizenship'”, in CACHET A. ea, Eds, Governance of Security in the Netherlands and Belgium, The Hague, Boom Legal Publishers, 2008, pp. 177-196.

Contact : ssmeets@ulb.ac.be-02/650.46.42

- Els Enhus is als licentiaat in de sociologie en doctor in de Criminologie verbonden aan de vakgroep Criminologie van de Vrije Universiteit Brussel. Ze is co-directeur van de interuniversitaire onderzoeksgroep Sociale Veiligheidsanalyse (VUB-UGent). Haar belangrijkste onderzoeksactiviteiten situeren zich in het domein van veiligheid en politie. Hierin wordt vooral de aandacht gericht op de concrete praktijken en cultuur van de verschillende actoren in veiligheid die geconfronteerd worden met het maatschappelijk discours binnen dit domein.

Contact : els.enhus@vub.ac.be-02/629.13.92

De auteurs danken Christine Schaut (FUSL) voor haar suggesties tijdens de voorbereidende fase van deze synthesenota. 


\section{Vaststellingen}

1. Voorafgaande opmerkingen. De omtrekken van het vraagstuk van de veiligheid en de preventie

a. "Veiligheid" werd aanvankelijk gebruikt om de bescherming tegen externe gevaren of de algemene afwezigheid van risico's aan te duiden. In de loop der jaren heeft deze term een meer beperkte en specifieke betekenis gekregen. Het is nu enerzijds een toestand die gekenmerkt wordt door de afwezigheid van burgerlijke onveiligheid. Dit laatste begrip wordt nu uitgelegd als de afwezigheid van wanorde, gevaar voor of dreigende wanorde. Anderzijds is het ook een specifiek interventiedomein dat de openbare ordehandhaving tot doel heeft. Maar er is geen eensgezindheid over het begrip burgerlijke onveiligheid. Voor sommigen is het een concrete ervaring (criminaliteit, de rol van slachtoffer), voor anderen een indirecte ervaring via de media. Op dezelfde manier kan het "onveiligheidsgevoel" dat met onveiligheid in verband wordt gebracht, de "angst voor een misdrijf" zijn, een gevoel van onbehagen dat te maken heeft met de achteruitgang van de sociale cohesie of, in bredere zin, met sociale onveiligheid. Onveiligheid is dus een sociale constructie. Veel studies tonen bovendien aan dat er geen verband is tussen onveiligheid en het onveiligheidsgevoel.

b. Bovendien werden de onveiligheidskwesties al snel verengd tot de stedelijke problemen met kleine en middelzware criminaliteit. Momenteel komen daar nog het "gebrek aan burgerzin" en "gebrek aan openbare orde" bij. Deze verenging verdringt niet alleen hele discussies naar de achtergrond, maar leidt ook tot lokalisering van de openbare middelen om de onveiligheid te bestrijden en tot concentratie van de aandacht op de openbare ruimten of ruimten die voor het publiek toegankelijk zijn.

c. Het is niet alleen moeilijk om precies te omschrijven wat "onveiligheid" inhoudt, maar ook om oplossingen voor dit verschijnsel af te bakenen. Vaak vertrekken ook de oplossingen immers van begrippen met meerdere betekenissen. Dit geldt voor 
de term "preventie" die centraal staat in het openbaar beleid. Het lijkt weliswaar of er een consensus bestaat over deze categorie van ingrepen, maar de omzetting in voorzieningen stelt een aantal theoretische en praktische problemen. Preventie biedt immers de mogelijkheid om onder één enkele term zeer diverse voorzieningen onder te brengen, zoals de verzadiging van een wijk door de politie of sociale bemiddeling, zonder de straathoekwerkers te vergeten. Er bestaat daardoor een reëel risico dat een eerder "sociale" actielogica wordt besmet met een eerder "strafrechtelijke" actielogica. Bovendien verdoezelt deze vaagheid vaak de verbanden met de repressie, die vaak als het tegenovergestelde wordt voorgesteld.

d. De onveiligheid rechtvaardigt weliswaar zeer uiteenlopende beleidsopties en voorzieningen, maar meestal wordt daarvan slechts de doeltreffendheid geëvalueerd en niet de gevolgen, de impact of de relevantie. Wij stellen dan ook vast dat het niet mogelijk is om een algemeen en gedetailleerd beeld te geven van de veiligheidssituatie in Brussel. De beschikbare cijfers (politiestatistieken en slachtofferenquêtes) verwijzen immers naar de politieacties of maken een te monolithische balans op. Het is daardoor niet mogelijk om een fijn onderscheid tussen de verschillende soorten slachtoffers te maken.

Deze beperkingen en de omvang van ons thema hebben ons ertoe gebracht om ons te concentreren op het beleid en op de voorzieningen die worden voorgesteld als oplossingen voor de onveiligheid en/of het onveiligheidsgevoel. Wij hebben ook het beleid en de voorzieningen die uitsluitend van strafrechtelijke aard zijn uitgesloten, omdat zij verwijzen naar federale bevoegdheden die het kader van deze synthese overschrijden.

\section{Wat Brussel specifiek maakt op veiligheidsgebied}

Alle grote steden hebben voortdurend met een aantal vraagstukken te kampen die van invloed zijn op de veiligheidssituatie. Als Belgische en Europese hoofdstad, tweetalig gewest, belangrijkste verkeersknooppunt en grote producent van rijkdommen is Brussel bovendien een buitenbeentje. Belangrijke veiligheidsproblemen in Brussel hebben te maken met de mobiliteit van de werknemers (pendelaars, verkeersveiligheid, enz.), verschuivingen in de bevolking (immigratie, internationale criminaliteit, enz.), de economische activiteiten (financiële, fiscale en milieucriminaliteit) of de ordehandhaving die te maken heeft met de (inter)nationale instellingen en de Europese topontmoetingen.

De complexiteit van de situatie in Brussel heeft ook met de lokale context te maken. Brussel heeft in 1977 niet meegedaan met de fusie-operatie van de gemeenten. Daardoor is de stad nu een mozaïek van 19 gemeenten met onderling grote verschillen op politiek, geografisch, ruimtelijk, demografisch, sociaal-economisch en etnisch gebied. Dit contrast wordt nog versterkt door de omvorming van de 19 gemeentelijke politiediensten in 6 lokale politiezones die telkens uit 2 tot 5 gemeenten bestaan. Deze hergroepering was bovendien niet ingegeven door argumenten als het soort criminaliteit of sociaal-economische of stedenbouwkundige kenmerken.

Maar in tegenstelling tot wat men zou kunnen denken, is de veiligheidssituatie in Brussel stabiel. De criminaliteitscijfers stijgen niet. De slachtoffergraad ligt weliswaar vrij hoog, maar een analyse van de cijfers toont aan dat er vrij frequent criminele feiten worden gepleegd, maar dat deze relatief niet zo zwaar zijn: 57\% van de ge- 
rapporteerde delicten zijn diefstallen en afpersingen ${ }^{1}$, terwijl slechts $7 \%$ inbreuken op de fysieke integriteit zijn. Het onveiligheidsgevoel ligt daarentegen wel hoger dan in de andere gewesten: 18,6\% van de Brusselaars zegt dat ze zich altijd of vaak onveilig voelen, tegenover $7 \%$ bij de Vlamingen en $11 \%$ bij de Walen.

\section{Voorzieningen inzake veiligheid en preventie}

Er wordt in Brussel op zeer veel niveaus en door zeer veel instanties een beleid gevoerd dat rechtstreeks met veiligheid heeft te maken. Deze situatie heeft twee gevolgen.

Enerzijds vindt men in Brussel, naast de lokale politiekorpsen (federale en gemeentelijke subsidies), subsidies op elk bevoegdheidsniveau: federale en/of regionale voor het stricto sensu veiligheidsbeleid (veiligheidscontracten, Brusselse preventiecontracten, contracten voor de Europese topontmoetingen, contracten voor administratieve sancties); gemeentelijke die te maken hebben met hulp aan en bescherming van de jeugd; Europese, federale, gewestelijke en lokale die te maken hebben met het beleid van stedelijke regulering en renovatie (grootstedelijke contracten, wijk- en handelswijkcontracten of lokale, gewestelijke of federale ad hoc projecten, die allemaal een impact op de veiligheid zouden moeten hebben) (zie bijlage 1).

Anderzijds is er een aanzienlijke diversiteit van de voorzieningen, al hebben deze gemeenschappelijke kenmerken:

- De wil om de veiligheidslogica en de sociale logica te integreren. Dit probeert men te bereiken via coördinatie-, overleg- en partnerschapmechanismen.

- Steeds meer aandacht voor de kwestie van het "gebrek aan burgerzin" en "overlast" in plaats van "criminaliteit".

- De leden van de "gemeenschap" wordt meer op hun verantwoordelijkheid gewezen.

- Er komen nieuwe, hybride functies, die tussen "veiligheid" en "sociale controle" in liggen (parkwachten, veiligheids- en preventieagenten, enz,).

- Geografische opdeling van de voorzieningen in territoria, per wijk.

Deze voorzieningen kunnen worden geklasseerd in functie van hun essentiële doelstellingen, zoals bepaald door de projectverantwoordelijken zelf:

a. De lokale voorzieningen die de openbare diensten dichter bij de bevolking brengen

De interfaces tussen de bevolking en de administratie of de lokale overheden: politiekantoren in wijken, het gerecht, de lokale administratie, de gemeentelijke bemiddelaars, de overlegassistenten, de ombudsman, enz.

De nabijheidsfuncties, om de openbare ruimte in het oog te houden, de bevolking gerust te stellen en het contact ermee te verbeteren: de wijkpolitie, het toezicht door de wijkagent, de stadswachten.

1 Deze categorie omvat onder andere de lichtste vormen, zoals gewone diefstallen, zonder geweld of inbraak. 


\section{b. De inrichting van de fysieke omgeving}

Men probeert de frequentie waarmee een probleem zich voordoet te verminderen door de veiligheid te bevorderen met een aangepaste inrichting van het openbaar domein (betere stadsverlichting, bescherming van zwakke weggebruikers, vuilnisbakken voor blikjes, toiletten, enz.) of door het inpalmen van de vrije ruimte (groenzones, speelpleinen, sportinstallaties, enz.). In deze categorie hoort ook de technische preventie thuis (fietsen graveren, beveiligingspremies, bezoek na een inbraak, enz.).

c. De bewaking van territoria

Over het algemeen krijgen drie soorten bewaking voorrang:

- Menselijke bewaking met personeel dat bekend is in de buurt.

- Technische bewaking: vaak worden er bewakingscamera's geïnstalleerd op de openbare weg, op sommige plekken die van strategisch belang worden geacht.

- Bewaking door de wijkbewoners: zeer uitzonderlijk in Brussel (wijkinformatienetwerken).

d. Levenskwaliteit en sociale verbanden

Om het leven in de wijken, de sociale woongebouwen of de scholen te verbeteren door de sociale verbanden te herstellen en de fysieke en/of sociale omgeving te verbeteren, worden verscheidene soorten stappen gezet:

- Oprichting van structuren die de inwoners in staat stellen om elkaar te ontmoeten en gemeenschappelijke projecten op te zetten (wijkhuizen, jeugdhuizen, straat- of wijkwerking, enz.)

- Conflictoplossing: sociale en schoolbemiddeling, wijkbemiddeling, schuldbemiddeling, enz.

- Wijkoverleg

- Scheppen van lokale banen: straatagenten, reiniging of kleine herstellingen, sociaal-culturele activiteiten, enz.

- Stadshernieuwing en heropleving van wijken.

e. Repressie van een gebrek aan burgerzin

De gemeentelijke administratieve boetes of systemen die steunen op een belasting van ongewenste gedragingen zijn gericht op de repressie van een gebrek aan burgerzin. Deze systemen zijn nu ruim verspreid (hun concrete toepassing wordt uitgelegd in MEERSCHAUT et al. 2008). 


\section{Vragen-problemen}

\section{Gebrek aan evaluatie}

Er bestaat geen betrouwbaar en relevant instrument dat tegelijk een algemeen beeld van Brussel en een fijne analyse van de lokale incidentie van veiligheidsproblemen oplevert. Er is niet alleen een schrijnend gebrek aan cijfers, maar als deze al bestaan, bieden ze niet de mogelijkheid om de reële onveiligheidstoestand te meten (noch de criminaliteit zelf, noch het onveiligheidsgevoel).

Bovendien bestaat er enerzijds in Brussel geen evaluerend quasi-experimenteel onderzoek (dat zich zou baseren op een "voor-na"- of een "hier-elders"-evaluatie) dat een causaal verband tussen de voorziening en de verwachte resultaten zou kunnen aantonen. Anderzijds stelt men vast dat de externe evaluaties van de impact of relevantie van de acties geleidelijk verdwijnen en plaats ruimen voor "interne" evaluaties. Deze laatste gaan vooral na of de verplichtingen die met diverse subsidies en het gebruik van financiële middelen gepaard gaan, worden nageleefd. Men kan bijgevolg geen precieze uitspraken doen over de doeltreffendheid van het overheidsoptreden in Brussel op veiligheidsgebied.

2. De moeilijkheid om het veiligheidsbeleid in een meer algemeen kader (welzijn) te situeren

De waanvoorstelling dat Brussel een gevaarlijke stad is, brengt sommigen ertoe om voor de stad een veiligheidsproject uit te tekenen dat enerzijds uitgaat van een fijnmazig gecontroleerd grondgebied, dat permanent wordt bewaakt en vol ordestrijdkrachten loopt en dat anderzijds de beheersing van het gedrag van als problematisch omschreven doelgroepen tot gevolg heeft.

Een van de meest verontrustende recente evoluties ter zake is de ontwikkeling van technische preventiemiddelen die weinig in vraag worden gesteld. De steeds talrijker wordende camera's wijzigen aanzienlijk het statuut van de openbare ruimte en de manier waarop de stad wordt beleefd door de bevolkingsgroepen die er wonen. Zij versterken het beeld dat de veiligheid niet het resultaat zou zijn van het vreedzaam en harmonisch samenleven van verscheidene bevolkingsgroepen, maar wel van bewaking. In dit opzicht is het onderscheid tussen geruststellen (onveiligheidsgevoel) en acties tegen criminaliteit (onveiligheid) nochtans bijzonder belangrijk.

\section{De moeilijkheid om een echt Brussels beleid te ontwikkelen}

De coördinatie en consistentie van de diverse gevoerde acties, zijn in Brussel duidelijk problematisch. Dit wordt nog verergerd door de recente opsplitsing van de territoria en van de instanties die het beleid voor criminaliteitspreventie toepassen, definiëren en evalueren enerzijds en anderzijds van het lokale politiebeleid.

In dit verband dient men ook te wijzen op de moeilijke positie van Brussel bij het werven van politieagenten. Zij worden hoofdzakelijk van buiten Brussel aangetrokken. De nieuwe agenten worden bij het begin van hun loopbaan voor een zeer korte periode (meestal twee jaar) ingezet in deze stad die ze niet kennen, waarvan ze de problemen slecht begrijpen en waarvan ze niet noodzakelijk houden. De politiediensten hebben dus gebrek aan personeel dat het terrein kent en zich er ook op lange termijn voor wil interesseren. 


\section{De moeilijkheid om de veiligheid op stadsniveau te bekijken}

Het veiligheidsbeleid wordt steeds meer op basis van de wijk als territoriale eenheid uitgewerkt. Men kijkt niet naar de consistentie van dit beleid, waardoor een versnipperd beeld van de stad, haar problemen en het te voeren beleid aan belang wint. De fenomenen die het gevolg zijn van de algemene evenwichten van de stad ontsnappen aan de analyse. Deze visie bekijkt onveiligheid bovendien steeds minder als het product van een bepaalde stadsconfiguratie en steeds maar als het resultaat van de aanwezigheid van vreemde lichamen of in elk geval van problematische elementen in het sociale weefsel.

\section{Het gebrek aan middelen}

Brussel dient weliswaar het hoofd te bieden aan een bijzondere veiligheidsproblematiek, maar kan de kosten daarvan nauwelijks dragen. De snelle uitbreiding van de politietaken en van het aantal politieagenten tijdens de laatste decennia is een zware last voor Brussel. Enerzijds is het probleem van het tekort aan politieagenten er zeer duidelijk voelbaar. De oorzaken daarvan zijn onder andere de verplichte tweetaligheid en de zwaardere werklast. Brussel heeft dus onvoldoende middelen om zijn eigen veiligheidsaanpak te ontwikkelen en aan zijn specifieke verplichtingen te voldoen.

Dit gebrek aan middelen heeft ook gevolgen voor het voorgestelde beleid. Door de politiehervorming hebben de lokale overheden nu minder greep op hun eigen politiemacht. Dit heeft de gemeenten ertoe gebracht om "nieuwe uniformen" aan te werven om een gedeelte van de lokale ordehandhaving te verzekeren. Men ziet daardoor dat bepaalde politietaken geleidelijk verschuiven naar stadswachten (toezicht door wijkagenten, vaststelling van gebrek aan burgerzin) of naar privé-organisaties (beheer van de parkeermeters). Deze verschuivingen werden niet in vraag gesteld voor wat de kwaliteit van de dienstverlening of de vaagheid van de bevoegdheidsafbakening betreft.

\section{Toename van het aantal vage en precaire functies}

De versnipperde middelen en financieringsbronnen hebben niet alleen een consistentieprobleem tot gevolg, maar ook een toename van het aantal functies op het terrein. Het resultaat is een kluwen van sociale werkers die aan instellingen of verenigingen zijn verbonden die zich op diverse manieren om de veiligheidsproblematiek bekommeren en die veel moeite ondervinden om als partners samen te werken.

Deze situatie levert twee grote problemen op. Het eerste is de vaagheid van de functies en de afwezigheid van een normenkader. De betrokkenen zijn daardoor verplicht om hun praktijk voortdurend "uit te vinden", zonder enige zekerheid dat deze ook zal worden erkend. Deze functies krijgen concreet gestalte op (micro)lokaal niveau, waardoor de praktijk zeer heterogeen wordt. Het tweede probleem heeft te maken met de grote mobiliteit van het personeel dat in deze diensten werkt. Hierdoor wordt het moeilijk om op lange termijn ervaring en kennis te vergaren. Deze mobiliteit is onder andere te wijten aan de weinig aantrekkelijke verloning van de betrokken functies en de precariteit van de contracten. Deze laatste zijn immers dubbel wisselvallig: enerzijds door de onzekere hernieuwing van de subsidies, anderzijds door de weinig benijdenswaardige statuten (contracten van bepaalde duur, 
deeltijdse contracten, precair statuut dat te maken heeft met programma's voor de activering van sociale uitkeringen).

\section{De gemeentelijke administratieve boeten}

De gemeentelijke administratieve boeten werden oorspronkelijk voorgesteld als een uitbreiding van de gemeentelijke bevoegdheden. De gemeenten zouden zo immers in staat zijn om autonoom het lokale veiligheidsbeleid te bepalen door overlast aan te pakken. Maar al snel bleek dat deze boeten een tweesnijdend zwaard zijn.

Inzake consistentie van het beleid stelt men vast dat er een gebrek aan harmonisering is tussen aangrenzende gemeenten. Dit leidt soms tot absurde situaties, vooral als men weet dat de politiekorpsen voor verscheidene territoria bevoegd zijn.

Inzake autonomie hangt de toepassing van het middel van de administratieve boeten voor gemengde inbreuken (administratief én strafrechtelijk) grotendeels af van de lokale politie en het parket. De lokale politie is bevoegd voor het vaststellen van de inbreuken en voor de materiële identificatie van de pleger; het parket kan de gemeenten verhinderen om dit middel te gebruiken voor dit soort inbreuken. In het gerechtelijk arrondissement Brussel gebeurt dit systematisch voor eenvoudige diefstallen waarvoor bijgevolg geen gemeentelijke administratieve verwerking mogelijk is.

De gemeentelijke autonomie is dus zeer relatief, vooral omdat het middel vandaag wordt voorgesteld als een instrument dat onontbeerlijk iks voor een gemeentelijk veiligheidsbeleid. De gemeenten worden steeds meer aangemaand om dit middel te hanteren. Doen ze dit niet, dan riskeren ze ervan beschuldigd te worden dat ze tolerant voor wanorde zijn, waaruit zwaardere criminaliteit zou kunnen voortkomen, zodat het (federale) strafrechtelijke systeem moet ingrijpen, wat dan weer duur is voor de belastingbetalers. 


\section{Mogelijke beleidsoplossingen}

\section{Cijfers, evaluatie en rationalisatie}

Brussel dient een systeem te ontwikkelen om zowel de veiligheidsproblemen als de impact en de relevantie van het ontwikkelde beleid te evalueren. Er moet bijgevolg binnen een zo ruim mogelijk kader worden nagedacht, waarin zowel het betrokken veld, de lokale diagnoses als de ruimste gevolgen van de gevoerde acties worden meegenomen. Een Brussels observatorium van de veiligheid en criminaliteitspreventie zit in de ontwerpfase ${ }^{2}$. Het zou één van de vele instrumenten van deze evaluatie moeten worden. Het observatorium zou moeten worden aangevuld met een ambitieuze financieringsstrategie op lange termijn van regelmatige externe evaluaties door onafhankelijke organisaties.

Het is niet alleen belangrijk om de impact van het beleid te evalueren. Vóór men nieuwe voorzieningen invoert, dient men te bepalen welke effecten men ervan verwacht en welke kosten eruit zullen voortvloeien. Dit betekent dat men, zodra men aan een project begint, de modaliteiten voor de follow-up ervan moet uitwerken.

\section{Het begrip veiligheidsbeleid verruimen tot het begrip stadsbeleid}

Als men het eens is met een ruime opvatting van het begrip veiligheid en met het idee dat zeer veel openbare actiemiddelen erop van toepassing zijn, dan dient men de architectuur zelf van het beoogde beleid te herzien. Men dient het veiligheidsbeleid dat steunt op de ordehandhaving zoveel mogelijk over te laten aan het federale niveau (de FOD Binnenlandse Zaken). Tegelijk dient men volop het veiligheidsgegeven in alle beleidsdaden van de stad te integreren. Het Vlaamse Gewest geeft hiervan een voorbeeld met zijn analyse in het 'Witboek stedenbeleid. Over stadsrepublieken en rastersteden'. Met zijn 'Plans de prévention et de proximité (PPP)' probeert ook het Waalse Gewest deze richting in te slaan.

De redacteurs van deze nota houden bijgevolg een pleidooi voor een echt stadsproject dat uitgaat van het begrip 'welzijn'. Dit is volgens hen een manier om de veiligheidsproblematiek en de sociale problemen die erdoor aan de oppervlakte komen, werkelijk ernstig te nemen. Deze evolutie houdt in dat er een nauwkeurige inventaris van alle huidige initiatieven en hun subsidiëringsmodaliteiten moet worden opgesteld.

\section{Bevoegdheden van de verschillende bevoegdheidsniveaus}

De institutionele complexiteit van Brussel is een belangrijk probleem. Toch hoeft de oplossing niet noodzakelijk in een radicale vereenvoudiging te worden gezocht. De diversiteit van de bevoegdheidsniveaus creëert ook de mogelijkheid om op het meest geschikte niveau in te grijpen. Men dient zich bijgevolg af te vragen welke schaal relevant is voor het overheidsingrijpen.

Zo is het wijkniveau ontegensprekelijk relevant om bepaalde beleidsopties te ontwikkelen. Maar dit mag niet het enige niveau zijn om de veiligheidskwesties aan te pakken. Men dient rekening te houden met evenwichten op gemeentelijk, gewestelijk en zelfs nationaal vlak. Brussel dient bijgevolg een beleid te ontwikkelen dat spe-

${ }^{2}$ BOCART 2008 
cifiek is voor het globale stadsniveau en zelfs mee te werken aan het opstellen van een beleid voor zijn hinterland.

Men dient zich in dit verband af te vragen welke rol er voor het Gewest is weggelegd aangaande coördinatie (bijvoorbeeld inzake gemeentelijke administratieve boeten) en stimulering van de actoren op het terrein. Op dezelfde manier is het essentieel dat een gedeelte van de inspanningen wordt besteed aan het opstellen van een kennisbeleid over de veiligheid.

Het Gewest moet ten slotte een gesprekspartner worden bij het beheer van de mobiliteit van het politiepersoneel.

\section{Financiering van een specifiek veiligheidsbeleid in Brussel}

Uit de bijzondere positie van Brussel en de specifieke kosten die ermee gepaard gaan, volgt ook dat de financiering van het veiligheidsbeleid en de politie op het grondgebied van het Gewest opnieuw moet worden geëvalueerd. Deze kwestie heeft te maken met de meer algemene problematiek van de financiering van het Gewest.

\section{Stabilisatie van het openbaar veiligheidsbeleid}

Het precaire karakter van de functies die in het kader van het veiligheidsbeleid worden gecreëerd, vormt een probleem. Deze functies moeten niet alleen beter worden omschreven en goed geëvalueerd, maar de functies die een goede beoordeling krijgen, moeten ook worden gestabiliseerd. Het is bovendien even essentieel om het tewerkgestelde personeel te stabiliseren. 


\section{Referenties}

BOCART, S. (2008) "Créer un observatoire de la criminalité", La Libre Belgique, 8 oktober, http://www.lalibre.be/actu/bruxelles/article/451227/creer-un-observatoire-de-lacriminalite.html

BRION, F. (2007) "Immigration, crime et discrimination. Recherches en Communauté française", Immigration et intégration en Belgique. État des savoirs, Louvainla-Neuve, Academia-Bruylant, 2007, 333-361.

CARTUYVELS Y., FRANSSEN A., HOUGARDY L., HUBERT H.-O., LEMAITRE A., SMEETS S., TORO F. (2003) Insécurité : un premier état des savoirs. Synthèse bibliographique relative à l'insécurité et au sentiment d'insécurité, Brussel, Koning Boudewijnstichting (www.frb.be).

DEVROE, E., BEYENS, K., ENHUS, E. (éd.) (2006) Zwart op wit ? Duiding van cijfers over onveiligheid en strafrechtsbedeling in België, Brussel, VUBpress.

EASTON, M., PONSAERS, P., ENHUS, E., ELFFERS, H., HUTSEBAUT, F., DEMARÉE, CH., VANDEVOORDE, M. (2008) Multiple Community Policing: Hoezo?, Brussel, Federaal Wetenschapsbeleid.

FRANSSEN, A.et SMEETS, S. (2008) "Between crime prevention and social cohesion policies. Analysis of a local experience of regulation in Brussels", Séminaire international Local context and prevention, dans le cadre l'Action coordonnée (6ème PCRD) Assessing Deviance, Crime and Prevention in Europe (CRIMPREV), Workpackage 6 "Public policies of prevention", Paris, 24-25 januari.

HOSTE J., DEHAES J., DUPONT K., MICHELS CH., ENHUS E. (éd.) (2004) De (nieuwe) functies inzake veiligheid en de buurtinformatienetwerken, Brussel, VUBpress.

MEERSCHAUT, K., PAUL DE HERT, P., GUTWIRTH, S., VANDER STEENE, A. (2008) "L'utilisation des sanctions administratives communales par les communes bruxelloises. La Région de Bruxelles-Capitale doit-elle jouer un rôle régulateur?", Brussels Studies, nr 18.

SMEETS, S., TANGE, C. (2003) "La collaboration policière à Bruxelles", in WITTE, E. et al., De Brusselse negentien gemeenten en het Brussels model. Les dix-neuf communes bruxelloises et le modèle bruxellois, Brussel, Larcier, pp. 119-140.

VAN CAMPENHOUDT, L., et al. (éd.) (2000) Réponses à l'insécurité : des discours aux pratiques, Brussel, Labor.

VAN PRAET S., TANGE C., SMEETS S. (2005) Les nouvelles fonctions de la sécurité publique, Brussel , SPF intérieur, 30 november.

VANDEVOORDE, N., VAEREWYCK, W., ENHUS, E., \& PONSAERS, P. (2003) Politie in de steigers. Bouwen aan gemeenschapsgerichte politiefuncties in een lokale context, Brussel, Politeia. 


\section{Bijlagen}

De voorzieningen voor preventie van de criminaliteit en de strijd tegen de onveiligheid in Brussel Source : FRANSSEN, SMEETS (2008)

\begin{tabular}{|c|c|c|c|c|c|}
\hline \multicolumn{6}{|l|}{ Politiebeleid } \\
\hline Type & Datum & $\mid \begin{array}{l}\text { Subsidië- } \\
\text { rend niveau }\end{array}$ & Doelstelling & \multicolumn{2}{|l|}{ Middelen } \\
\hline $\begin{array}{l}\text { Nationaal veilig- } \\
\text { heidsplan }\end{array}$ & $\begin{array}{l}2007- \\
2010 \\
\text { (laatste } \\
\text { plan) }\end{array}$ & Federaal & \begin{tabular}{|l|} 
Definiëren van de bijdrage \\
van de geïntegreerde \\
politie tot het federale \\
criminaliteitsbeleid
\end{tabular} & \multicolumn{2}{|c|}{$\begin{array}{l}\text { Federale politie: opdrachten en prioritaire doelstellingen en spreiding van } \\
\text { de middelen inzake personeel en materiaal. } \\
\text { Lokale politie: prioritaire elementen. Basis voor de zonale veiligheidsplan- } \\
\text { nen. }\end{array}$} \\
\hline $\begin{array}{l}\text { Zonaal veiligheids- } \\
\text { plan }\end{array}$ & $\begin{array}{l}2007- \\
2010 \\
\text { (laatste } \\
\text { plannen) }\end{array}$ & $\begin{array}{l}\text { Lokaal } \\
\text { (Federaal) }\end{array}$ & \begin{tabular}{|l|}
$\begin{array}{l}\text { Politiebeleid van de lokale } \\
\text { politie }\end{array}$ \\
\\
\end{tabular} & \multicolumn{2}{|c|}{$\begin{array}{l}\text { Lokale politie: } \\
\text { prioritaire opdrachten en doelstellingen; capaciteit voor de uitvoering van } \\
\text { de opdrachten van gerechtelijke politie en administratieve politie; bijdrage } \\
\text { van de lokale politie tot de uitvoering van de opdrachten van federale aard } \\
\text { eventueel opdrachten en doelstellingen die specifiek zijn voor een gemeen- } \\
\text { te van de zone }\end{array}$} \\
\hline \multicolumn{6}{|c|}{ Stedelijk veiligheidsbeleid } \\
\hline Type & Datum & $\begin{array}{l}\text { Subsidië- } \\
\text { rend niveau }\end{array}$ & Doelstelling & \multicolumn{2}{|l|}{ Middelen } \\
\hline \multirow{6}{*}{$\begin{array}{l}\text { Veiligheids-contrac- } \\
\text { ten (België) } \\
\text { (Strategische veilig- } \\
\text { heids- en preven- } \\
\text { tieplannen sinds } \\
2007 \text { ) } \\
103 \text { Belgische } \\
\text { gemeenten, } 14 \\
\text { Brusselse gemeen- } \\
\text { ten (2007-2010) }\end{array}$} & \multirow{6}{*}{1992} & \multirow{6}{*}{$\begin{array}{l}\text { Federaal } \\
\text { (vooral } \\
\text { FOD Bin- } \\
\text { nenlandse } \\
\text { Zaken) } \\
\text { Brussels } \\
\text { Gewest } \\
\text { Lokaal }\end{array}$} & \multirow[t]{6}{*}{$\begin{array}{l}\text { Bestrijding van de stede- } \\
\text { lijke onveiligheid en van } \\
\text { het onveiligheidsgevoel }\end{array}$} & $\begin{array}{l}\text { Politie } \\
\text { (verdwijnt in } \\
\text { 2002) }\end{array}$ & $\begin{array}{l}\text { Modernisering van de lokale politie; buurtpolitie (wijk- } \\
\text { agenten en decentralisatie van de commissariaten); } \\
\text { gezin- en jongerenbrigades; verbetering van de relaties } \\
\text { politie - migranten (overlegassistent); verbeterd onthaal }\end{array}$ \\
\hline & & & & Sociaal & $\begin{array}{l}\text { Jeugdhuizen en straathoekwerking } \\
\text { Gemeenschaps- en bemiddelingshuizen (sociaal, per } \\
\text { wijk) } \\
\text { Opvanghuizen voor drugsverslaafden } \\
\text { Onthaal van daklozen }\end{array}$ \\
\hline & & & & $\begin{array}{l}\text { Situationele pre- } \\
\text { ventie }\end{array}$ & $\begin{array}{l}\text { Bewaking van de openbare ruimte (stadswachten); } \\
\text { openbare verlichting; bewaking met videocamera's }\end{array}$ \\
\hline & & & & $\begin{array}{l}\text { Slachtofferop- } \\
\text { vang en -hulp }\end{array}$ & $\begin{array}{l}\text { Opvang van slachtoffers } \\
\text { Eerstelijns juridische hulp }\end{array}$ \\
\hline & & & & (1996) Gerecht & Begeleiding van alternatieve maatregelen \\
\hline & & & & $\begin{array}{l}\text { Analyse van de } \\
\text { onveiligheid }\end{array}$ & $\begin{array}{l}\text { Lokale veiligheidsdiagnose (2006) } \\
\text { Criminele cartografie }\end{array}$ \\
\hline $\begin{array}{l}\text { "Brusselse" preven- } \\
\text { tie-contracten } \\
\text { (Brussel) } \\
19 \text { gemeenten }\end{array}$ & 2002 & $\begin{array}{l}\text { Brussels } \\
\text { Gewest }\end{array}$ & Preventie van criminaliteit & \multicolumn{2}{|l|}{ Preventieagent } \\
\hline $\begin{array}{l}\text { Contracten "Euro- } \\
\text { pese topontmoe- } \\
\text { tingen" } \\
\text { (Brussel) } \\
6 \text { politiezones } \\
\text { (19 gemeenten) }\end{array}$ & 2003 & Federaal & $\begin{array}{l}\text { De veiligheid garanderen } \\
\text { tijdens Europese topont- } \\
\text { moetingen }\end{array}$ & \multicolumn{2}{|c|}{$\begin{array}{l}\text { Aanwerving van stadswachten } \\
\text { Overuren van politieagenten } \\
\text { Taalopleiding } \\
\text { Materiaal aankopen } \\
\text { Telecommunicatie verbeteren }\end{array}$} \\
\hline $\begin{array}{l}\text { GAS-contracten } \\
\text { (België) } \\
15 \text { Belgische ste- } \\
\text { den en gemeenten, } \\
\text { de stad Brussel }\end{array}$ & 2006 & Federaal & $\begin{array}{l}\text { Zorgen voor de invoering } \\
\text { van gemeentelijke admini- } \\
\text { stratieve sancties (GAS) }\end{array}$ & \multicolumn{2}{|l|}{ Bemiddelaar } \\
\hline $\begin{array}{l}\text { GAS-contracten } \\
\text { (België) } \\
19 \text { gemeenten }\end{array}$ & 2006 & $\begin{array}{l}\text { Brussels } \\
\text { Gewest }\end{array}$ & $\begin{array}{l}\text { Zorgen voor de invoering } \\
\text { van GAS }\end{array}$ & \multicolumn{2}{|c|}{ Sanctiebevoegde ambtenaar } \\
\hline
\end{tabular}




\begin{tabular}{|c|c|c|c|c|}
\hline \multicolumn{5}{|c|}{ Regulerend stedelijk beleid } \\
\hline Type & Datum & $\begin{array}{l}\text { Subsidië- } \\
\text { rend niveau }\end{array}$ & Doelstelling & Middelen \\
\hline $\begin{array}{l}\text { Wijkcontracten } \\
\text { (Brussel) } \\
\text { sinds } 1994,44 \\
\text { wijken, } 10 \text { gemeen- } \\
\text { ten }\end{array}$ & 1994 & $\begin{array}{l}\text { Brussels } \\
\text { Gewest } \\
\text { Federaal } \\
\text { Lokaal }\end{array}$ & $\begin{array}{l}\text { Sociale herwaardering van } \\
\text { de wijk } \\
\text { Herwaardering en renova- } \\
\text { tie van de openbare ruim- } \\
\text { te en de gebouwen }\end{array}$ & $\begin{array}{l}\text { Bestaande woningen saneren en nieuwe woningen bouwen } \\
\text { De openbare ruimte verfraaien en herinrichten } \\
\text { Wijkuitrusting bouwen (opvang jonge kinderen, wijkhuizen, sportzalen, } \\
\text { lokalen voor verenigingen) } \\
\text { De inwoners van de wijk tewerkstellen } \\
\text { Participatie van de inwoners }\end{array}$ \\
\hline $\begin{array}{l}\text { Handelswijk-con- } \\
\text { tracten (Brussel) } \\
7 \text { gemeenten }\end{array}$ & 2006 & $\begin{array}{l}\text { Brussels } \\
\text { Gewest } \\
\text { Federaal }\end{array}$ & $\begin{array}{l}\text { Verbetering van het dy- } \\
\text { namisme en de aantrek- } \\
\text { kelijkheid van het Gewest }\end{array}$ & $\begin{array}{l}\text { Activiteiten creëren (de vestiging van nieuwe winkels bevorderen, winkelke- } \\
\text { tens begeleiden, ...) } \\
\text { Inrichting van de ruimte en toegankelijkheid (creëren van woongelegenheid, } \\
\text { toegang tot de wijk, sociale diversiteit en gecoördineerd optreden van de } \\
\text { openbare diensten), } \\
\text { Aantrekkelijkheid (de pluspunten van de wijk bekendmaken) }\end{array}$ \\
\hline $\begin{array}{l}\text { Grootstedelijke } \\
\text { contracten (België) } \\
7 \text { Brusselse ge- } \\
\text { meenten }\end{array}$ & 2000 & Federaal & $\begin{array}{l}\text { Verbetering van de le- } \\
\text { venskwaliteit, de levens- } \\
\text { omstandigheden, de } \\
\text { veiligheid en de economi- } \\
\text { sche herwaardering van } \\
\text { de steden. } \\
\text { De sociale deficits van de } \\
\text { kwetsbare bevolkings- } \\
\text { groepen compenseren. }\end{array}$ & $\begin{array}{l}\text { Stadsrenovatie ( } 40 \% \text { van het budget) } \\
\text { Culturele en sportieve activiteiten } \\
\text { Toezicht op de openbare ruimte } \\
\text { Preventie in scholen en alfabetisering } \\
\text { Sociale integratie en creëren van lokale banen } \\
\text { Openbare netheid }\end{array}$ \\
\hline $\begin{array}{l}\text { Stedenfonds } \\
\text { (Vlaanderen en } \\
\text { Brussel) } \\
13 \text { Vlaamse ge- } \\
\text { meenten } \\
+ \text { Brussels Gewest }\end{array}$ & $\begin{array}{l}2003- \\
2007\end{array}$ & \begin{tabular}{l|} 
Vlaamse \\
Gemeen- \\
schaps- \\
commissie \\
(Brussels \\
Gewest)
\end{tabular} & $\begin{array}{l}\text { De groeiende kloof tussen } \\
\text { arm en rijk in de stad } \\
\text { bestrijden. } \\
\text { De levenskwaliteit verho- } \\
\text { gen. }\end{array}$ & $\begin{array}{l}\text { Financiering van kleine projecten die door de gemeenten worden voorge- } \\
\text { steld: } \\
\text { Stadsrenovatie } \\
\text { Renovatie van multifunctionele aard } \\
\text { Projecten van sociale economie }\end{array}$ \\
\hline $\begin{array}{l}\text { Urban } 1 \text { en } 2 \text { (Eu- } \\
\text { ropa) } \\
3 \text { Brusselse ge- } \\
\text { meenten (1994), } 5 \\
\text { Brusselse gemeen- } \\
\text { ten (2000) }\end{array}$ & $\begin{array}{l}1994- \\
1999 \\
2000- \\
2006\end{array}$ & $\begin{array}{l}\text { Europa } \\
\text { (Federaal) }\end{array}$ & $\begin{array}{l}\text { Sociale en economische } \\
\text { herwaardering van de } \\
\text { wijken }\end{array}$ & $\begin{array}{l}\text { 1994: bedrijvencentra, loketten voor lokale economie, bedrijven voor socia- } \\
\text { le economie, buurtinfrastructuren (cyberspace, wijkhuizen, sportruimten, } \\
\text { enz.) } \\
\text { 2000: } \\
\text { Buurtinfrastructuur en -uitrusting: culturele centra, jobhuizen, wijkhuizen } \\
\text { Renovatie van braakliggende industriële panden } \\
\text { Toegang tot nieuwe technologieën en e-administratie } \\
\text { Lokale ontwikkeling (creatieve en expressie-workshops voor jongeren, enz.) }\end{array}$ \\
\hline $\begin{array}{l}\text { URBACT } 1 \text { en } 2 \\
\text { (Europa) } \\
183 \text { steden (UR- } \\
\text { BACT 1) }\end{array}$ & $\begin{array}{l}2002- \\
2006 \\
2007- \\
2013\end{array}$ & $\begin{array}{l}\text { Europa } \\
\text { (Federaal) } \\
\text { (Lokaal) }\end{array}$ & $\begin{array}{l}\text { De stadsontwikkeling } \\
\text { bevorderen: economie en } \\
\text { tewerkstelling en sociale } \\
\text { cohesie. }\end{array}$ & $\begin{array}{l}\text { Oprichting van netwerken en themawerkgroepen om praktijken en kennis } \\
\text { uit te wisselen tussen de steden van het Urban-programma }\end{array}$ \\
\hline
\end{tabular}

